Man and Nature

L'homme et la nature

\title{
Gershom Carmichael and the Natural Jurisprudence Tradition in Eighteenth-Century Scotland
}

\section{James Moore et Michael Silverthorne}

Volume 1, 1982

URI : https://id.erudit.org/iderudit/1011790ar

DOI : https://doi.org/10.7202/1011790ar

Aller au sommaire du numéro

Éditeur(s)

Canadian Society for Eighteenth-Century Studies / Société canadienne d'étude du dix-huitième siècle

ISSN

0824-3298 (imprimé)

1927-8810 (numérique)

Découvrir la revue

Citer cet article

Moore, J. \& Silverthorne, M. (1982). Gershom Carmichael and the Natural Jurisprudence Tradition in Eighteenth-Century Scotland. Man and Nature / L'homme et la nature, 1, 41-54. https://doi.org/10.7202/1011790ar

Copyright (c) Canadian Society for Eighteenth-Century Studies / Sociéte canadienne d'étude du dix-huitième siècle, 1982
Ce document est protégé par la loi sur le droit d'auteur. L'utilisation des services d'Érudit (y compris la reproduction) est assujettie à sa politique d'utilisation que vous pouvez consulter en ligne.

https://apropos.erudit.org/fr/usagers/politique-dutilisation/ 


\section{Gershom Carmichael and the Natural Jurisprudence Tradition in Eighteenth- Century Scotland}

No discussion of the origins of the Scottish enlightenment would be complete without an expression of homage to Gershom Carmichael, the first occupant of the Chair of Moral Philosophy at the University of Glasgow and the predecessor of Francis Hutcheson and Adam Smith. He has sometimes been called, following Sir William Hamilton, "the real founder of the Scottish school of philosophy" but it is not entirely clear what Sir William intended to convey by this pronouncement. ${ }^{1}$ His teaching and writings have been characterized more cautiously but perhaps more judiciously by James McCosh as "the bond which connects the old philosophy with the new in Scotland."2 Carmichael was a transitional thinker of some importance; but McCosh's description, like Sir William Hamilton's, continues to beg the question: in what respect may Carmichael be considered an innovator in his teaching and in his writing? He was not a philosopher of common and of moral sense like the 3rd Earl of Shaftesbury and Francis Hutcheson; Carmichael was aware of this development in moral philosophy in the early eighteenth century and he rejected it. He did not claim to be an experimental philosopher or to be the Newton of the moral sciences; this distinction was claimed by and for later thinkers of the Scottish enlightenment, more skeptical in their approaches to moral and political philosophy than Carmichael. Indeed, considering that he wrote and taught entirely in Latin, and that for most of his teaching career he was a regent in the old system of Scottish university education, ${ }^{3}$ it might be more appropriate to locate him in what might be called the preenlightenment in Scotland than in the luminous company which was soon to follow. ${ }^{4}$ But in one crucial respect at least Carmichael's career as a teacher and writer of moral philosophy was the source of much that was distinctive and of enduring significance in the Scottish enlightenment. For it was above all Carmichael who was responsible for establishing the natural jurisprudence tradition in the Scottish universities. It was not just his decision to make Pufendorf's smaller work, De Officio Hominis et Civis, the set text in moral philosophy at Glasgow, a practice also followed by John Loudon and later in Edinburgh by Sir John Pringle, and continued at Glasgow by Francis Hutcheson. It was rather the notes and supplements which Carmichael appended to the text, and which Hutcheson considered of more value than 
the text itself, which supplied many of the moral and political ideas that lie behind the numerous treatises, tracts and lectures on jurisprudence which were to prove such a fecund source of speculation on human nature and society. In order to appreciate the distincitive turn given the study of moral philosophy and natural jurisprudence in Scotland by Carmichael it may be helpful to provide some biographical details about him.

Gershom Carmichael was born in London, in 1672, the son of a Presbyterian clergyman, Alexander Carmichael, who had been deprived of his church in Scotland and exiled to England earlier in the same year. There he became minister of a congregation of expatriate Scots Presbyterians. ${ }^{5}$ Alexander Carmichael and his wife appear to have been acutely sensible of the alien condition of their life in England, as may be inferred from their choice of the name Gershom for their son, which derives from the name of Moses' son given in Exodus 8:22: "a stranger born in a strange land." The elder Carmichael died in 1677, leaving behind a tract which was published as Believers Mortification of Sin by the Spirit or Gospel-holiness advanced by the power of the Holy Ghost (London, 1677 and Glasgow, 1730), a document as dour as the title would suggest. Gershom's mother remarried another clergyman, Sir James Fraser of Brea, ${ }^{6}$ who brought the family back to Edinburgh in 1687, where Gershom enrolled at the University of Edinburgh and graduated with an M.A. in 1691. ${ }^{7}$ Carmichael was appointed a regent at St. Andrews in 1693 but resigned later in the same year to obtain an M.A. from Glasgow where he became a regent in 1694, a position he held until 1727 when he became Professor of Moral Philosophy at the same university. ${ }^{8} \mathrm{He}$ died in 1729.

Carmichael was a vigorous supporter of the Revolution of 1688 and the Hanoverian succession. His convictions were reinforced no doubt by those of his patrons; in particular, he owed his appointment at Glasgow in part to the patronage of a distant kinsman, Lord Carmichael, who had been made Chancellor of the University of Glasgow in 1692 and Secretary of State for Scotland in $1696 .{ }^{9}$ In helping to arrange the appointment of his kinsman, Lord Carmichael was not merely obliging a distant relative, he was contributing to the religious and political realignment of the Scottish universities which occurred at the Revolution. By an Act of Parliament (July $4,1690)$ all principals and regents were required to subscribe an oath of allegiance and to declare their belief in the articles of faith of the Presbyterian Church of Scotland. ${ }^{10}$ Gershom Carmichael liked to contend (particularly in one notable riposte to Sir Richard Steele) that such subscription in no way inhibited members of the university in their inquiries. ${ }^{11}$ And his own theological views were sufficiently unorthodox that we must take him at his word, on this point, at least. As a regent he was responsible for teaching his students moral and natural philosophy, logic, and metaphysics. He published two sets of philosophical theses (on which his students were examined, in 1699 and 1707, on metaphysics and moral philosophy, respectively ${ }^{12}$ ) and three major works: his edition of Samuel Pufendorf's De Officio Hominis et Civis juxta Legem Naturalem. Libri Duo. Supplementis et Observationibus in Academicae Juventutis usum auxit et illustravit Gershomus Carmichael (Glasgow 1718, Edinburgh 1724), an introduction to logic, Breviuscula 
Introductio ad Logicam (Glasgow 1720, Edinburgh 1722), and Synopsis Theologiae Naturalis, sive Notitiae, De Existentia, Attributis et Operationibus Summi Numinis . . Studiosae Juventutis usibus accomodata (Edinburgh 1729), which contained, he said, the most important part of metaphysics and pneumatology. He insisted in the preface to the last of these works that his teaching be confined in his later years to natural theology and moral philosophy, which he took to be nothing but natural jurisprudence.

In the preface to his edition of De Officio Hominis et Civis Carmichael remarked on the great advances in human knowledge which had occurred since the beginning of the seventeenth century. No one with the least tincture of learning could be ignorant, he said, of the remarkable progress made in natural philosophy in the previous century, but no less striking was the improvement in moral philosophy. It was the incomparable Grotius who had restored moral philosophy to the splendour it had enjoyed in ancient times. And from that time, the most erudite and celebrated scholars of Europe, as if aroused by the sound of a trumpet, had vied with one another in the pursuit of moral knowledge. He mentions Selden and Hobbes in this connection, not without profound reservations, however, since Selden's work was confined by his preoccupation with Hebrew learning, and Hobbes, he said, set out not to improve the study of the law of nature but to corrupt it. It was Pufendorf who put the materials of Grotius in a more logical order adding what was necessary to produce a systematic treatise in moral philosophy. The publication of Pufendorf's De Jure Naturae et Gentium (1672) and the compendium of that work, his De Officio Hominis et Civis (1673) persuaded many that the study of moral philosophy or ethics properly understood was nothing but the study of natural jurisprudence or the demonstration of the duties of man and the citizen from knowledge of the nature of things and the circumstances of human life.

Pufendorf's works were widely adopted by professors of moral philosophy for the use of students in European universities. They became best known perhaps in the translations of those works by Jean Barbeyrac, Professor of Civil Law and History of the College of Lausanne (1710-1717) and later Professor of Jurisprudence at the University of Groeningen (1717-1744). ${ }^{13}$ But there were many annotated editions and discussions of Pufendorf's work, particularly of De Officio Hominis et Civis, and in 1709 a dozen of these commentaries were collected in a single volume. One comment in that volume had a particular impact on readers generally and on Carmichael in particular. It was an extended critique of the philosophical principles on which Pufendorf had chosen to base his study of the law of nature. The commentator, the famous Leibniz, held that Pufendorf's first principles were basically unsound; this did not prevent the work from having substantial value for the reader, he hastened to acknowledge, since much of the argument in the book did not logically follow from the first principles. There were three basic mistakes in the premises of Pufendorf's discussion of natural law. The first was Pufendorf's insistence that the study of the law of nature should be confined to this life, without consideration of the prospect of happiness or misery after death. Secondly, Pufendorf's understanding of natural law was limited to the external manifestations of human conduct with 
insufficient consideration of the spirit in which men act, their motives and intentions. Thirdly, given these deficiencies in Pufendorf's understanding of the law of nature, it was not surprising that he had an unsatisfactory notion of the efficient cause of natural law or of what obliges us to obey the law of nature. Leibniz concluded his criticism of Pufendorf on this note:

"This has not a little relevance for the practice of true piety: it is not enough indeed, that we be subject to God just as we would obey a tyrant; nor must He be only feared because of His greatness, but also loved because of His goodness . . . . To this, lead the best principles of universal jurisprudence which collaborate also with wise theology and bring about true virtue." 14

Leibniz's proposal that any attempt to offer an understanding of the law of nature more satisfying than Pufendorf's would be well advised to search for it in the collaboration of wise theology with natural jurisprudence found a most receptive reader in Carmichael. He had been remodelling Pufendorf's natural jurisprudence on just these lines in his moral philosophy lectures from the turn of the century. In his edition of Pufendorf, Carmichael advised his readers that he had

"taken particular care that the obligations imposed by the law of nature be deduced from the existence, the perfection and the providence of the deity: so that the manifest bond between moral knowledge and natural theology might be clearly exhibited."15

He also tells us that the first and second supplements which he had added to the text, and which contained a demonstration of the law of nature, its derivation from the supreme being, and its principal maxims or prescriptions were offered by way of response to the criticisms of Pufendorf's theory of natural law made by the excellent Leibniz. Unlike Jean Barbeyrac who defended Pufendorf's separation of natural religion and natural jurisprudence, Carmichael, in an initiative which would have significant consequences for the teaching of moral philosophy, insisted that the two were inseparable.

"I have asserted more than once," he said, in his Synopsis Theologiae Naturalis, "that a genuine philosophy of morals must be built upon natural theology as its foundation, as it were, and that every well founded distinction of good and evil in our actions . . . must be deduced from the perceived relation of those actions to God, that is, to our knowledge of the existence, perfections and providence of the supreme being." 16

It is worth underlining that it was natural theology which was to serve as the foundation for a system of natural jurisprudence. Carmichael was not concerned to link natural jurisprudence to Christian theology or the study of the revealed word. It was an error, he said, to suppose that one could discover the rights and duties of men and citizens from consultation of holy scripture; in fact, the revealed law, or as he prefers to call it, the positive law of God, offered little guidance in these matters. And, for that reason, he had always 
opposed the teaching of what is popularly called Christian ethics in the universities. ${ }^{17}$ Because the scriptures provided little guidance for the citizen and for the ruler, they had to be supplemented by observations unsystematically culled from pagan writers, and the resulting mish-mash (farraginem) had engendered entirely fallacious ideas of governments such as the ideas of divine and indefeasible hereditary right, which Carmichael also characterized by the term, hallucinatio. It would have been much better to have followed the lead of the natural theologians and natural jurists who did not attempt to find guidance in holy writ on subjects where the scriptures remain silent but who sought direction instead from the nature of things and of man.

What were the sources of Carmichael's natural theology? In his Synopsis Theologiae Naturalis (1729) he appears to combine three distinguishable traditions. He made use of what Hume was to call experimental theology, or arguments for the existence of a supreme being from evidence of design in the physical world. He made reference to the plethora of writings on this subject, mentioning works by Cheyne, Pelling, Ray, Derham and Nieuwent, which one encounters everywhere, he said, and which indicate continued progress in our knowledge of natural things and the confirmation this knowledge affords of the existence of a supreme architect or designer. ${ }^{18}$ In this connection, he observed that one might as well suppose that Virgil's Aeneid was composed by the ink flowing fortuitously down the pages as suppose that matter somehow accommodated itself to laws of nature without the intervention of an intelligent world orderer; an observation which may bring to mind the remark of the skeptic in Hume's Dialogues, that our experience of the creation of universes is so slight that faced with the argument from design, we are in much the same position as an illiterate person who is shown a copy of the Aeneid and is asked to form a judgment about the existence and the abilities of the poet. ${ }^{19}$ But Carmichael does not attach overriding importance to the argument from design in the physical or corporeal world. He finds more weighty the argument from design in the moral and political world, underlining in particular the description by Malebranche of the way the human mind, by the mediation of the feelings and instincts of the body, unites itself with the perceptible world and with the minds of other men by the instinctive tendency to imitate and sympathize with the feelings of others. Since the ability of men to live in society and in peace with others depends so much upon natural instincts and feelings of this kind which human beings could never have invented for themselves, we must conclude that our instinctive propensities for social life are better traced to the providence of the supreme being. ${ }^{20}$ In a third line of argument which proves the most important ingredient in Carmichael's natural theology, we find him calling attention to the imperfections of matter which would lack both form and motion, if it were not shaped and moved by a superior immaterial cause. Even human beings cannot be said to generate their nobler and more sublime modes of thought from their corporeal or material natures. We find rather in man a longing or aspiration to think in ways unbounded by his material existence:

"He arrives by long chains of reasoning at knowledge of the most abstract 
and recondite truths, not only of things past but of infinite vistas of possible things; thought ascends in its meditations beyond the bounds of earth to contemplate the idea of a perfect being, it aspires to beatific enjoyment of this vision of perfect being. . . ." 21

The third element in Carmichael's natural theology is the theology of the Schoolmen; the ideas and the language are more reminiscent of Aquinas than of writers in the Presbyterian canon, and, however paradoxical it may seem, Carmichael was quite explicit about his indebtedness to this earlier theological tradition:

"I cannot avoid confessing that the doctrines of the Scholastics, at least of the more ancient ones, seem to me to be more correct and more consistent with reason and even with Sacred Scripture in this, by far the gravest part of philosophy; in particular, in the articles concerning the unity of God, the simplicity and the other communicable attributes thence flowing, likewise concerning the knowledge and decrees of God, and concerning his providence as ruler and preserver, than are those opinions which are opposed to them today. . . and are very much worn in the hands of the student body: whence I have not been ashamed to introduce to them other ideas. . .and I have not refrained from use of words and phrases which are Scholastic, although they may grate on more delicate ears, when a more Latin mode of signifying the sense with equal precision did not occur to me."22

Carmichael attached great significance to this element. The principle of aspiration, of longing for complete fulfillment (beatitudo) in this life and in the hereafter was the principle that would answer Leibniz's question of the end or aim of the study of the law of nature: the end of the study was knowledge of how one must conduct one's life if one would enjoy eternal happiness. ${ }^{23}$ The same principle also pointed to the appropriate inspiration of moral conduct: one must act in a spirit of love and reverence for the supreme being. And finally, it supplied the efficient cause or motivation for observance of the law of nature in a way that avoided the impious notion of the supreme being as a tyrant who enjoys authority over men only because of the penalties he will impose for disobedience. The authority which God enjoys over human beings is authority over rational beings and is properly called majestas or imperium as distinct from His power over other creatures and things which is properly called dominium. ${ }^{24}$ The significance of this distinction between imperium and dominium will become evident in considering Carmichael's contribution to the theory of property and the theory of allegiance to government.

Both the theory of property and the theory of allegiance as one discovers them in Carmichael's writings and lectures are noteworthy above all because they bring to bear upon the thought of Pufendorf and the natural jurisprudence tradition the political ideas of John Locke. We do not know what prompted Carmichael to take up Locke's Two Treatises of Government and employ them extensively as a gloss upon the argument of Pufendorf. But as early as 1702-03 in his lectures on ethics, which take the form of a 
commentary on Pufendorf, we find him referring to the Second Treatise of Civil Government for a discussion of property which was found to be preferable to the discussions of property in Pufendorf and Grotius. ${ }^{25}$ The date is significant, for there would be no problem of accounting for the use of Locke's Second Treatise to provide a corrective for Pufendorf's theories of property and allegiance to government after 1706. Barbeyrac's work was published in that year, and Barbeyrac, through his associations with Pierre Coste, Jean Le Clerc and the Huguenot community in Amsterdam was well acquainted with Locke's political ideas and Barbeyrac corresponded with Locke in the last years of his life. ${ }^{26}$ There is no evidence of this kind which connects Carmichael directly with Locke or with the friends of Locke in Holland. But there seems nonetheless some reason to suppose that it was the Dutch connection with the Scottish universities and the fact that the Second Treatise was widely acclaimed in Holland in the 1690s that would have called it to the attention of Carmichael. This would be consistent with the close connections between the Dutch and Scottish universities in the sevententh and eighteenth centuries, a connection which was responsible, it has been said, for the great emphasis on Roman law in Scottish legal education in this period, and it would also be consistent with the attempt of William Carstares (the leading adviser on Scottish policy to King William) to reform Scottish university education along Dutch lines. ${ }^{27}$ But whatever the source of Carmichael's attachment to Locke's Second Treatise, it was his use of that text (along with Barbeyrac's use of it to much the same end) which not only made Locke a political thinker of some importance in the Scottish enlightenment, but also recast Locke's ideas in ways that would stimulate new directions of inquiry by later Scottish thinkers. The recasting was due in part to Carmichael's retention of the frame of reference of Pufendorf's jurisprudence and in part to the Scholastic orientation of his natural theology and jurisprudence.

The immediate attractiveness of Locke's theory of property for Carmichael was that it allowed him to explain how men could have acquired a right of ownership in things not yet owned by anyone. It was a problem which had arisen from the description by Pufendorf of the state of nature or original condition of things as a condition of negative community as contrasted with the condition of positive community in which things were shared by men in accordance with the agreement or consent of all members of the community. What appeared paradoxical to Carmichael was Pufendorf's contention that ownership of property in negative community depended on the same kind of agreement or consent. A much better explanation of the origin of property in the state of nature or of negative community had been provided by Locke: men may be considered to own those things they have occupied by their labour, without waiting upon the agreement or consent of others. ${ }^{28}$

Now it has come to be regarded as controversial whether Locke ever supposed that the state of nature was a negative community in Pufendorf's sense. It has been argued that Locke's theory of the state of nature was a theory of positive not of negative community, that his labour theory of property was a theory of the way men mix their personalities with the things of the common, that it was a theory of individuation not of occupation in the 
classical juridical sense. ${ }^{29}$ But whatever Locke's intentions may have been in elaborating his theory of property, the labour theory of property was recognized by moral philosophers like Francis Hutcheson and George Turnbull, who adopted it, and by critics of the labour theory like David Hume, as a theory of occupation, as a theory of the way men may be supposed to rightfully occupy a previously unoccupied world. It was this formulation of the theory which prompted Adam Smith, Henry Home and others to ask what kind of labour or what sort of occupation men might have engaged in when they began to occupy a hitherto unoccupied world. ${ }^{30}$ The form in which the question came to them derives immediately from Francis Hutcheson. But Hutcheson's natural jurisprudence (not his moral psychology) was in turn taken over very largely from the work of Carmichael, as Hutcheson generously acknowledged:

"The learned will at once discern how much of this compend is taken from the writings of others, from Cicero and Aritotle; and to name no other moderns, from Pufendorf's smaller work, De Officio Hominis et Civis, which that worthy and ingenious man, the late Professor Gershom Carmichael of Glasgow, by far the best commentator on that book, has so supplied and corrected that the notes are of much more value than the text." 31

Remarkably, perhaps, the labour theory of property became so closely identified with the commentators on Pufendorf's natural jurisprudence in the early eighteenth century, specifically with the names of Barbeyrac and Carmichael, that, in some texts, (as in translations of Bishop Cumberland's De Legibus Naturae) Locke's authorship of the labour theory drops entirely from sight and reference is made only to the presentations of Barbeyrac and Carmichael. ${ }^{32}$

One other feature of Carmichael's formulation of the labour theory of property remains to be mentioned. It is one of the notable features of theories of commercial society in Britain in the eighteenth century that such theories are formulated, typically - by Bernard de Mandeville, David Hume, Adam Smith, John Millar, and others - without reference to Locke and his labour theory of property. ${ }^{33}$ But if Hume, Adam Smith and the later thinkers of the Scottish enlightenment formed their ideas of Locke's political thought from compends of natural jurisprudence like Carmichael's, then their diffidence concerning Locke's theory of property may be readily explained and appreciated. For Carmichael's construction of the labour theory of property and his use of Locke's political ideas generally remained within the conceptual horizons of the Scholastic tradition with its insistence on the duties of human beings to limit possessions and transcend attachments to material things.

Carmichael's clearest articulation of these duties appears in his third supplement to the first book of De Officio entitled "On the Duties of Man to His Own Mind." Here he reminds the reader that while external things are needed to preserve life and to provide for the needs of others, no man requires more than a finite and small amount of such things for himself and for his family. Any man who misapplies his mind in the accumulation of wealth is 
engaged in a purposeless or literally endless activity alien to the nature of man. We have a duty to ourselves not to be overly concerned about our possessions for such things may be lost or stolen or destroyed; we have a duty to avoid appropriation in excess of our immediate and foreseeable needs, for the surplus will surely spoil and thereby frustrate the end of property which is simply to sustain life; we have, at all times, the overriding duty to maintain ourselves in a spirit of reverence for the supreme being, a mental inclination which cannot fail to direct the mind to higher concerns when we have provided by our labour for the needs of ourselves and our dependents. ${ }^{34}$ In this highly Scholastic account of human duties with respect to external things one finds little support for a reading of the labour theory of property which would be of service to a theorist of commercial society. It was a monastic or ascetic construction of the labour theory which could only apply in a society characterized by relations of production and exchange very different from those typical of commercial societies. In order to recognize the kind of society Carmichael had in mind when he conceived his theories of property and morality we must turn to his description of the manner in which any legitimate society may be supposed to have begun.

Carmichael's account of the origin of civil or legitimate societies took its point of departure from Pufendorf's theory of the original contract amended, or so he claimed, by Locke's theory of consent. Here the problem addressed by Carmichael had been posed by the skeptical and historical critics of the original contract theory (notably Bayle) who had contended that neither human nature nor history afforded grounds for the belief that societies and governments had their beginnings in agreements or contracts: the origins of all societies were to be found in a perception of the utility or convenience of submission to the craft or force of ambitious men. ${ }^{35}$ This skeptical critique of the original contract theory had made an impression on at least two of the commentators on Pufendorf's work; Gerhard Gottlieb Titius (of Leipzig) and Jean Barbeyrac both conceded to the skeptics that the idea of a social contract or original agreement to live peaceably in society was indeed a mistake. But both commentators went on to insist that the skeptical arguments applied only against the first of the contracts in Pufendorf's account of the origin of societies and governments; there was a second contract in Pufendorf's scheme, between members of the society and their sovereign or ruler which was to the first contract "what scaffolds are with respect to the structure of . . . buildings." ${ }^{36}$ The second or political contract, the contract of allegiance, had a foundation in history as well as in human nature and the entire case for the theory of the original contract might be best supposed to rest upon it.

This concession to the skeptical critique of the original contract theory by such eminent men (clarissimi viri) as Titius and Barbeyrac seemed to Carmichael a most unfortunate lapse on the part of those distinguished jurists. There could be no doubt that crafty and ambitious men were involved in the beginnings of societies, but such men could expect to enjoy support for their schemes only if they presented arguments which seemed persuasive to the people they hoped to induct into the society. ${ }^{37}$ The presumption that force could be used to establish a society begged the question: for the presence of armed force presupposed established social arrangements; those who employ 
force must already enjoy power. And in order to discover the source of power (imperium) one must find it in human relations which are quite different from the relations characteristic of the exercise of force, the relations of command and obedience. In pursuit of this theoretical goal Carmichael embarked upon an extended gloss upon the Roman law distinction between imperium and dominium.

There is a natural power which great landowners or landlords may enjoy which can be called imperium soli or power derived from the land. The landlord acquires this power by his willingness to acknowledge that anyone who lives on the land has the right to occupy and work the land and establish a household there. The obligation to acknowledge this right of dominium in the land plainly followed from God's gift of the earth to men to occupy and use for the preservation of themselves and their families and the corresponding duty of men to limit their occupancy of the earth so that others may enjoy dominium in it. The concession of parts of his estate to others was bound to diminish the wealth of the landlord, but such diminution was entirely consistent with the duties of men with respect to external things: it could not fail, however, to engender a sense of obligation in all his beneficiaries. And this was the source of natural power derived from the land or imperium soli. There was no need then to look with the skeptics and historians for the origin of imperium in force or in the craft and guile of ambitious men; it was already present in those heads of households who enjoyed recognition and support from all those they had obliged. ${ }^{38}$ On this basis, the beginnings of civil power (imperium civile) could be readily explained: it must be presumed to have originated in an agreement or contract among men already in enjoyment of natural power to live in society, to establish a government and finally, to transfer their power or imperium to the ruler or rulers by particular promises of allegiance. The entire transaction might be distinguished into three separate pacts as Pufendorf had done or more conveniently described as one original contract which contained the force of the various pacts described by Pufendorf. In either case there could be no doubt that the origin of all legitimate societies and governments could be traced to an original contract or contracts and the concessions made by earlier jurists to the skeptics and historians should be withdrawn.

Carmichael thought that his presentation of the theory of the original contract was consistent with Locke's theory of consent as presented in the Second Treatise, chapter VIII. And his belief that his natural jurisprudence was supported by the authority of Locke was reinforced, no doubt, in the minds of the later generations of natural jurists and moral philosophers, by Francis Hutcheson's repeated linking of Carmichael's work with Locke's. ${ }^{39}$ But just as Carmichael's version of the labour theory of property was found to differ in crucial respects from Locke's formulation of the theory, one finds a similar divergence in their theories of the original contract. One of the most distinctive constituents of Locke's model, his theory of trust, is conspicuously lacking: instead, Carmichael supposed, with Pufendorf, that governments derived their authority from an exchange of promises; and this version of the original contract theory was the version criticised by Hume, Adam Smith and others. Secondly, Carmichael believed that the original contract theory was 
corroborated in history and experience, as did Francis Hutcheson and the Scottish critics of the theory, notwithstanding the allowance made by Locke himself that arguments taken from history to prescribe how governments ought to be conducted, "from what has been to what should of right be" have "no great force." And finally, it would seem to have been Carmichael's elaborate derivation of civil power from the natural or moral power of the obliging landowners, an argument which may have been suggested to him in part by Locke,' as he claimed, but also by Grotius and by Pufendorf himself, which prompted Hutcheson to conclude that the parties to the original contract were independent landowners and that ownership of land was the best foundation for civil government and for the maintenance of high standards of civic virtue.

Now Hutcheson had his own reasons for supposing that land was the material foundation of government inasmuch as his political thinking was strongly influenced (as Carmichael's was not) by the political writings of Harrington and the classical republican tradition. But Hutcheson's subscription to Carmichael's version of the theory of the original contract and his insistence, with Carmichael and Locke, on the natural independence of individuals and societies, identified for later Scottish jurists and political theorists a tradition in which liberty or independence was supposed to be best secured by an original contract entered into by men who enjoyed independence as owners of land. It was a tradition which was soon challenged. And in this light one may perhaps recognize in the critiques of the theory of the original contract by David Hume in his Political Discourses and Adam Smith in his Lectures on Jurisprudence one element in the more general argument of both thinkers that the societies which offered the most favourable conditions for liberty or independence were not, as their immediate predecessors had claimed, landed societies. A better prospect for the liberty of individuals and societies was afforded by commercial societies notwithstanding the deleterious effects of commerce on other aspects (mental, moral and military) of social life. ${ }^{40}$

In the revised and quite distinctive form in which Carmichael presented the natural jurisprudence tradition one may find then at least some of the problematic formulations which were taken up by later thinkers of the Scottish enlightenment. It would be necessary in any treatment of Carmichael's work which aspired to be more comprehensive to consider still other features of his natural jurisprudence: his formulation of the law of nature and the manner in which he proposed to reconcile the duties of sociability, and self-preservation; his theory of the family and of the duties of parents with respect to the education of their children; a denunciation of slaves and the right of conquest which claimed the authority of Locke, but was in fact more thoroughgoing in its opposition to slavery and in its defence of the land and the liberty of conquered people than anything written by Locke. And we have seen that it was Carmichael's construction of the labour theory of property and the theory of the original contract (indebted both to Pufendorf and to Locke but different from them both) which was carried over into the moral philosophy of Francis Hutcheson and which challenged the more skeptical and more historically minded philosophers of a later 
generation. In the range of his concerns, Carmichael was indeed representative, as Dugald Stewart observed, of the natural jurisprudence tradition which dominated the study of moral and political philosophy in the Scottish Universities early in the century. ${ }^{41}$ But in the particular turn which Carmichael gave that tradition - in his attempt to ground natural jurisprudence in natural theology, in his concern for the independence of individuals and societies, in his (no doubt idiosyncratic) use of the political thought of John Locke - he must be regarded as a modestly original thinker whose ideas formed an indispensable part of the movement of thought that culminated in the Scottish enlightenment.

James Moore

Concordia University

Michael Silverthorne

McGill University

\section{Notes}

The authors take this opportunity to express their gratitude for financial assistance given them by the Social Sciences and Humanities Research Council of Canada and the Humanities Council of McGill University.

This cryptic but often cited remark was made by Sir William Hamilton in a note to Dugald Stewart's "Account of the Life and Writings of Thomas Reid, D.D.," in The Works of Thomas Reid (Edinburgh 1846), I, 30n.

${ }^{2}$ James McCosh, The Scottish Philosophy: Biographical, Expository, Critical, from Hutcheson to Hamilton (London 1875), p. 36.

${ }^{3}$.John Veitch, "Philosophy in the Scottish Universities," Mind, II (1877) 74-91 and 207-234 locates Carmichael at the beginning of the era of independent philosophical inquiry in Scotland which followed upon the termination of the regenting system:

"Remarkably enough with the first man appointed to the professoriate in Glasgow, we have the commencement of independent investigation . . . Both by date and habit of thought, Carmichael may be taken as the link between the regenting and the professoriate, between the old thought and the new." (p. 209).

${ }^{4}$ For a description of Carmichael's teaching and of the reputation he enjoyed in his own time, see Robert Wodrow, Analecta: or Materials for a History of Remarkable Providences (Edinburgh 1842-43), IV, 95-96 and David Murray, Memoirs of the Old College of Glasgow (Glasgow 1927), pp. 506-8. For more recent discussion of Carmichael, there is a short article by W.L. Taylor, "Gershom Carmichael: A Neglected Figure in British Political Economy," South African Journal of Economics, 13 (1955), 252.55 which is devoted mainly to his contribution to the theory of value or of the natural price of commodities. Hans Medick, Naturzustand und Naturgeschichte der bürgerlichen Gesellschaft (Göttingen: Vandenloeck und Ruprecht, 1973), pp. 296-305 also contains useful material. The reader may wish to approach the latter through a review article by David Kettler, "History and Theory in the Scottish Enlightenment," Journal of Modern History, 48 (1976), 95-100.

${ }^{5}$ Hew Scott, Fasti Ecclesiae Scoticanae: the Succession of Ministers in the Church of Scotland from the Reformation (Edinburgh: Oliver and Boyd, 1928), VII, 489, III, 319; Philip O. Williams, "The Founders' Hall Meeting," Journal of the Presbyterian Historical Society of England, 2 (1922), 133-38.

${ }^{6}$ Fraser of Brea enjoyed a certain reputation in Presbyterian circles through the eighteenth century for the sanctity of his life and writings, particularly for his memoirs, or Memories of the Life of Sir James Fraser of Brea, written by himself (Edinburgh 1738). See also Hew Scott, Fasti Ecclesia Scoticanae, V, 15-16.

'A Catalogue of the Graduates of the Faculties of Arts, Divinity, and Law of the University of Edinburgh since its Foundation, ed. David Laing (Edinburgh 1858), p. 141. 
${ }^{8}$ Munimenta Alme Universitatis Glasguensis (Glasgow 1854), III, 396. Robert Wodrow, Analecta, IV, 95-96 and David Murray, pp. 506-8.

9 Munimenta, III, 309, 583.

${ }^{10}$ James Coutts, A History of the University of Glasgow (Glasgow 1909), pp. 165-72. See also R.L. Emerson, "Scottish Universities in the eighteenth century, 1690-1800," Studies in Voltaire and the Eighteenth Century, 167 (1977), 453-74.

${ }^{1}$ De Officio Hominis et Civis (1724), address to the reader (lectori benevolo), pp. XIV-XV, n. A review of Carmichael's edition of Pufendorf in Acta Eruditorum (Leipzig) 58 (1727), 45-48 takes Carmichael's response to Steele as its point of departure and goes on to examine the implications of Carmichael's theological ideas for his natural jurisprudence, focusing particularly on his theory of the family.

12 Theses Philosophicae. . Sub Praesidio Gerschomi Carmichael (Glasgow, 1699), and Theses Philosophicae. . . Sub Praesidio Gerschomi Carmichael (Glasgow, 1707).

${ }^{13}$ Samuel Pufendorf, Le Droit de la nature et des gens . . . traduit du latin par Jean Barbeyrac avec des notes du traducteur et une préface qui sert d'introduction à tout l'ouvrage (Amsterdam, 1706). Subsequent references to this work will be to the fourth edition, in English, Of the Law of Nature and Nations . . . to which are added all the large notes of $\mathrm{Mr}$. Barbeyrac, translated from the best edition (London, 1729). Barbeyrac's translation of Pufendorf's smaller work, Les Devoirs de l'homme et du citoyen was published in Amsterdam in 1707. Subsequent references to this work will be to an edition published together with Jacques Burlamaqui's Elémens du droit naturel (1747), (Paris, 1820).

${ }_{14}$ G.W. Leibniz, "Opinion on the Principles of Pufendorf," in The Political Writings of Leibniz, trans. and ed. by Patrick Riley, (Cambridge: Cambridge Univ. Press, 1972), p. 72.

${ }_{15}$ De Officio Hominis et Civis (1724), address to the reader, p. xvi.

${ }^{16}$ Synopsis Theologiae Naturalis (1729), p. 9.

17 De Officio Hominis et Civis, pp. $\mathrm{x} \cdot \mathrm{xi}$

${ }^{18}$ Synopsis Theologiae Naturalis, p. 18

19 David Hume, Dialogues Concerning Natural Religion, ed. Norman Kemp Smith, (London: Thomas Nelson and Sons, 1947), pp. 166-67.

${ }^{20}$ Synopsis Theologiae Naturalis, p. 22. Nicholas Malebranche, De la recherche de la vérité (Paris, 1965), I, p. 120.

${ }^{21}$ Synopsis Theologiae Naturalis, p. 20.

${ }^{22}$ Ibid., Preface, pp. 7-8.

${ }^{23}$ De Officio Hominis et Civis, Supplement I, pp. i to xi, address to the reader, p. xvii and notes to author's preface VI (1) and (3).

${ }^{24}$ Synopsis Theologiae Naturalis, pp. 70-71.

${ }^{25}$ Glasgow University Library Ms. Gen. 168: "Ethicae sive Jurisprudentiae Naturalis Compendiosum Certamen. Magistro autore Gershomo Carmichael, 1702-03," fol. 152ff. and Hans Medick, pp. 301-03.

${ }^{26}$ Bodleian Library Ms. Locke, C.3, fol. 140-44. On Barbeyrac's friendship with Le Clerc, Coste, etc. see Annie Barnes, Jean Le Clerc, et la Republique des Lettres (Paris: E. Droz, 1938).

27 Peter Stein, "The Influence of Roman Law on the Law of Scotland," The Juridical Review, 8, N.S. (1963), 205-45 and Roger Emerson, n. 10.

${ }^{28}$ De Officio Hominis et Civis, I, XII, II, (1) pp. 212-216. See also Barbeyrac's discussion in S. Pufendorf, Of the Law of Nature and Nations, IV, 365.

${ }^{29}$ James Tully, A Discourse on Property: John Locke and his Adversaries (Cambridge: Cambridge Univ. Press, 1980).

${ }^{30}$ This discussion is developed more fully in "Locke and the Scottish Jurists," in John Locke and the Political Thought of the 1680's (forthcoming), ed. Gordon Schochet.

${ }^{31}$ Francis Hutcheson, $A$ Short Introduction to Moral Philosophy (Glasgow, 1747) p.i.

${ }^{32}$ Richard Cumberland, A Treatise of the Law of Nature, trans. John Maxwell, (London, 1727), p. 315 and Traité philosophique des lois naturelles, trans. Jean Barbeyrac, (Amsterdam, 1744), pp. 346-48.

${ }^{33}$ See J.G.A. Pocock, "The Mobility of Property and the Rise of Eighteenth-Century Sociology" in Theories of Property: Aristotle to the Present, ed. Anthony Parel and Thomas Flanagan, (Waterloo, Ont.: Wilfrid Laurier Univ. Press, 1979), pp. 146-47; Donald Winch, Adam Smith's Politics (Cambridge: Cambridge Univ. Press, 1978), passim; Thomas Horne, The 
Social Thought of Bernard de Mandeville (New York: Columbia Univ. Press, 1977).

${ }^{34}$ De Officio Hominis et Civis. Supplement III, pp. 98-99.

${ }^{35} \mathrm{P}$. Bayle, Nouvelles Lettres à l'occasion de la Critique générale du Calvinisme de Maimbourg, Lettre XVII, Sect 2, cited by Barbeyrac in his notes to Pufendorf's Of the Law of Nature and Nations, Book VII, Chapter 1, Section VII, note 1, p. 629.

${ }^{36}$ Gerhard Gottlieb Titius, Observationes in Samuelis de Pufendorf De Officio Hominis et Civis Juxta Legem Naturalem (Lipsiae, 1703), Observations DLV, Sect. VI, p. 560 and Barbeyrac's note in Pufendorf, Of the Law of Nature and Nations, VII, Ch. II, Sect. VIII, n. 1, p. 641.

${ }^{37}$ De Officio Hominis et Civis, Book II, Chap. V, Section VII, n. 1, pp. 365-66.

${ }^{38}$ Ibid., Book II, Chap. VI, Section IX, Note 1, pp. 373-79.

${ }^{39}$ Francis Hutcheson, A Short Introduction to Moral Philosophy, pp. 286 and 310.

${ }^{40}$ Adam Smith, Lectures on Jurisprudence, ed. by R.L. Meek, D.D. Raphael and P.G. Stein, (Oxford: Clarendon Press, 1978), pp. 314-318, 402-4. An Inquiry into the Nature and Causes of the Wealth of Nations, ed. by R.H. Campbell and Andrew Skinner, (Oxford: Clarendon Press), I, p. 412. Donald Winch, Adam Smith's Politics, chs. 3, 4 and 5.

${ }^{41}$ Dugald Stewart, "Dissertation: Exhibiting the Progress of Metaphysical Ethical and Political Philosophy since the Revival of Letters in Europe," The Collected Works of Dugald Stewart, Esq., F.R.S.S., ed. by Sir William Hamilton, (Edinburgh, 1854). XI, 177-78. 